\title{
Effects of the Hydrolysable Oak Tannins on the Quail Performance
}

\author{
Mesut Karaman, Trefa Kamal Mohammed Azize, Mehmet Sait Ekinci*
}

Animal Science Department, Agriculture Faculty, Kahramanmaras Sutcu Imam University, 46100 Kahramanmaraş, Turkey

\section{A R T I C LE IN F O}

\section{Article history:}

Received 10 May 2016

Accepted 17 November 2016

Available online, ISSN: $2148-127 \mathrm{X}$

Keywords:

Japanese quail

Feed intake

Feed conversion

Hydrolysable oak tannin

Growth performance

\section{*Corresponding Author:}

E-mail: sekinci@ksu.edu.tr

\section{A B S T R A C T}

In the present study effects of different levels of hydrolyzed oak tannin on Japanese quail, live body weight and live body weight gain, food intake, food conversion efficiency and mortality rate were investigated. Therefore, a total of 240 quails were weighed and divided into 4 treatment groups each with 3 replicates containing 20 birds and reared in flat for 42 days as experimental period. While one of the groups was fed control diet with no additives ( $0 \%$ tannin A), other groups were fed with the different percentages of tannin on their diets, which are $0.5 \%$ (B), $1.0 \%$ (C), $1.5 \%$ (D) respectively. It has been observed that Japanese quails that fed the oak tannin containing diet had slower growth rate and poorer feed conversion efficiency and high mortality rate than birds fed with a tannin-free diet.

Türk Tarım - Gıda Bilim ve Teknoloji Dergisi, 4(12): 1085-1087, 2016

\section{Hidrolize Meşe Tanininin Bıldırcınlarda Performans Üzerine Etkisinin İncelenmesi}

\section{A K A L E B İ L G İ S İ}

Geliş 10 Mayıs 2016

Kabul 17 Kasım 2016

Çevrimiçi baskı, ISSN: 2148-127X

\section{Anahtar Kelimeler:}

Japon bildırcını

Yem tüketimi

Yem dönüşümü

Hidrolize meşe tanini

Büyüme performans1

\section{Ö Z E T}

Hidrolize meşe tanininin Japon bıldırcınlarının canlı ağırlık, canlı ağırlık kazancı, yem tüketimi, yem dönüşümü ve yaşama gücü üzerindeki etkileri araştırılmıştır. Bu amaçla toplam 240 bıldırcın dört grup ve üç tekerrürlü ve her bir tekerrürde 20 bıldırcın olacak şekilde 42 günlük deneme kurulmuştur. Denemede hayvan rasyonlarına farklı oranlarda meşe tanini eklenmiştir. Bu guruplar, \%0 tanin A (kontrol grubu), \%0,5 (B), \%1,0 (C), $\% 1,5$ (D) tanin içermektedir. Araştırma sonucunda meşe tanini içeren rasyonlarla beslenen bıldırcınlarda daha düşük büyüme performansı, düşük yem dönüşümü ve yüksek ölüm oranlarına sebebiyet verdiği gözlemlenmiştir.

*Sorumlu Yazar:

E-mail: sekinci@ksu.edu.tr

\section{Introduction}

On January 2006, the European Union banned the use of antibiotic growth promoters in animal nutrition. Consequently, many approaches have been attempted to prevent or control diseases and to stimulate growth performance by using different plant compounds (herbs, organic acids, essential oils) seem to be candidates of interest as alternative to growth promoters (Vilarino et al., 2009) and tannins represent one of several categories of useful antimicrobial and anti-nutritional factors (Cowan, 1999).

Tannins are water-soluble polyphenolic compounds that can be found in significant quantities in plant tissue. The chemical structure of tannins is highly variable. The hydrolysable tannins are polyesters of gallic acid, pyrogallol, resorcinol and simple sugars, while condensed tannins are group of polyhydroxy flavan-3-ol oligomers and polymers of carbon-carbon bound flavonoids (Schofield et al., 2001). Both these classes of tannins are rich in highly reactive hydroxyl groups, which emanate from each of the benzene rings and form complexes with proteins, including enzymes (Mangan, 1988; Khanbabaee and Van Ree, 2001), resulting in a remarkable reduction in the biodegradation of the fibrolytic polymers such as cellulose and hemicellulose in the rumen (Priolo et al., 2000). Both hydrolysable and condensed tannins are generally regarded as anti-nutritional factors for 
ruminants, because of depression of feed intake and dry matter digestibility (McSweeney et al., 2001), but their capacity to precipitate proteins reversibly at rumen $\mathrm{pH}$ may be nutritionally beneficial since tannin-protein complexes are stable at the $\mathrm{pH}$ range of 3.5 to 7.0 (Mangan, 1988).

The aim of the current experiment was to determine the effect of hydrolysable oak tannin on the growth performance, feed intake, feed conversion ratio and mortality rate of Japanese quails.

\section{Materials and Methods}

The experiment was conducted under animal care regulations in the Kahramanmaraş Sütçü İmam University, Animal Science Department, Avian Research Units. Japanese Quails (Coturnix coturnix japonica) that used in this experiment were obtained from parent stock of Kahramanmaraş Sütçü İmam University, Animal Science Department, Avian Research Units. Each cage was supplied with a plastic feeder and a drinker inside the cage. The characteristics of experimental diets were given in Table 1. The quails fed beginner diets containing hydrolysable tannin $(0.0,0.5,1.0,1.5 \%)$ and water $a d$ libitum for 0-3 weeks. The quails fed growing diets containing hydrolysable tannin $(0.0,0.5,1.0,1.5 \%)$ and water ad libitum for 4-6 weeks. Therefore four experimental diets (A, B, C and D) was obtained. Hydrolysable tannin from AR-TU KIMYA SAN. TİC .A.Ş, in Turkey.

Table 1 Composition of the experimental diets for Quail chicks

\begin{tabular}{l|cc}
\hline \multicolumn{1}{c|}{ Parameters } & BD & GD \\
\hline DM, \% & 88 & 88 \\
ME Kcal /kg & 3100 & 3200 \\
CP, \% & 23 & 19 \\
C oil, \% & 4.8 & 5.34 \\
CF, \% & 3.13 & 3.03 \\
C ash, \% & 5.62 & 4.9 \\
Methionin, \% & 0.6 & 0.5 \\
Lysine, \% & 1.35 & 1.27 \\
Ca, \% & 1 & 0.9 \\
Total phosphorus, \% & 0.6 & 0.53 \\
Available phosphorus \% & 0.5 & 0.45 \\
Sodium, \% & 0.17 & 0.16 \\
Linoneic Acid, \% & 2.44 & 2.76 \\
\hline BD:Begin
\end{tabular}

BD: Beginner Diet (0-3 weeks), GD: Growing Diet (4 weeks-slaughter)

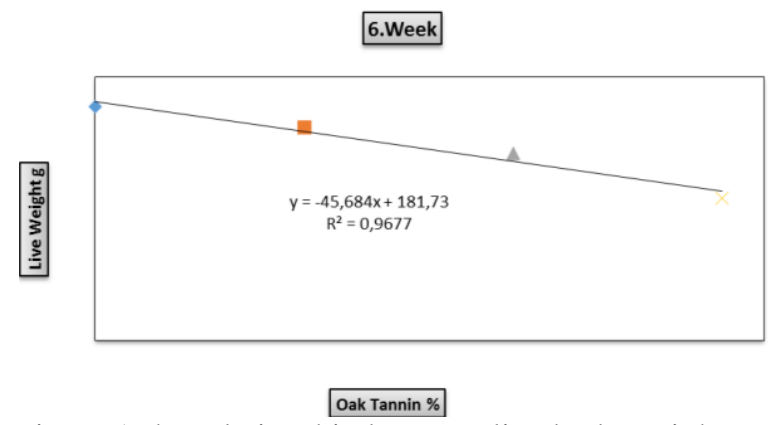

Figure 1The relationship between live body weight and supplementation dose of oak tannin
Birds were individually weighed in the early morning before receiving any food and water at weekly intervals during the experimental period. Live body weight (LBW), live body weight gain (LBWG), feed intake (FI), feed conversion ratio (FCR), and mortality rate were recorded and calculated weekly. The mean values of growth performance, feed intake, feed conversation ratio with standard error mean after six weeks experiments were subjected to one-way analysis of variance. When significant treatment effects were observed, differences among treatment means were tested by the multiple range test of Duncan.

\section{Result and Discussion}

The effect of tannin on growth performance, feed intake, feed conversation and mortality of Japanese quails was given in Table 2.

At the beginning of the experiment there are no significant $(\mathrm{P}>0.05)$ differences among live body weight means of quails. The live weights ranged from 8.40 to 8.8 . This result is in agreement with those reported by Cerit (1997), Özcan et al., (2001) and Nazlıgül et al., (2005). The supplementation of oak tannin had a significant $(\mathrm{P}<0.01)$ effect on the FiBW which ranged from 108.15 to $177.78 \mathrm{~g}$. FiBW of quail decreased with increasing dose of oak tannin.

The relationship between live body weight and supplementation dose of oak tannin is given in Figure 1. There was $45.68 \mathrm{~g}$ decreased with one unit increase in oak supplementation.

The FiBW of quails fed diet $\mathrm{A}$ is consistent with finding of Aggrey et al (2003), Özcan et al., (2001) and Nazlıgül et al., (2005). As can be seen from Table2 quails fed with diets including oak tannin had considerably low FiBW. These results are in agreement with findings of Ibrahim et al., 1988; Nyachoti et al., 1997; Trevino et al., 1992; Vilarino et al., 2009; Mahmood et al., 2008.

As can be seen from Table 2, BWG, FI ranged from 99.48 to 168.90 and 516.75 to $680.08 \mathrm{~g}$ with the highest BWG and FI for quails fed with control diet. BWG and FI decreased with increasing dose of oak supplementation whereas FCR increased with increased oak supplementation. Feed intake and FCR obtained for control diet is in agreement with findings of Cerit (1997) and Sarica (1998). On the other hand supplementation of oak tannin decreased the feed intake. This result is consistent with findings of Ibrahim et al. (1988), Nyachoti et al. (1997), Trevino et al. (1992), Vilarino et al. (2009), Mahmood et al. (2008).

As can be seen from Table 2 the oak supplementation had a significant deleterious effect on mortality of quails. The mortality rate of quails ranged from 10.0 to $25.01 \%$ with the highest mortality rate obtained for quails fed with diet supplemented with $1.5 \%$ of oak tannin.

Although some researchers suggested that low level of hydrolyzed tannin from chestnut had some positive effect on broiler such as improved BWG and FCR, the hydrolyzed tannin from oak had a significant negative effect on FI, BWG and mortality of quails possibly associated with detrimental effect of high doses of hydrolyzed tannin from oak. It is well known that tannin 
in diets with combines with nutrients especially protein, decreasing the digestibility of nutrients in diets, which is possibly associated with low level of FI and BWG. The effects of condensed tannin are generally associated with low FI and poor growth performance since the condensed tannin in diets are not absorbed but completely excreted (Jimenez-Ramsey et al., 1994). On the other hand, hydrolyzed tannins in diets are hydrolyzed in digestive system and absorbed but not completely excreted. The high level of hydrolyzed tannin from oak seems to be toxic to quails since the tannin from oak would be hydrolyzed and absorbed through the intestine of quails fed with diets including oak hydrolyzed tannin. Therefore hydrolyzed tannin from oak not only had a negative effect on the FI and BWG but also had a detrimental effect on the mortality.

Table 2- Effects of oak tannin on growth performance, feed intake, feed conversation and mortality of Japanese quails

\begin{tabular}{l|cccc}
\hline \multicolumn{1}{c|}{ Parameters } & Group1 $(\mathrm{A})$ & Group2 $(\mathrm{B})$ & Group3 $(\mathrm{C})$ & Group4(D) \\
\hline Beginning & $8.88 \pm 0.30 \mathrm{a}$ & $8.40 \pm 0.23 \mathrm{a}$ & $8.88 \pm 0.14 \mathrm{a}$ & $8.67 \pm 0.18 \mathrm{a}$ \\
FiBW & $177.78 \pm 2.43 \mathrm{a}$ & $161.73 \pm 5.11 \mathrm{ab}$ & $142.20 \pm 10.14 \mathrm{~b}$ & $108.15 \pm 5.14 \mathrm{c}$ \\
BWG & $168.90 \pm 2.30 \mathrm{a}$ & $153.33 \pm 4.91 \mathrm{ab}$ & $133.32 \pm 10.27 \mathrm{~b}$ & $99.48 \pm 5.16 \mathrm{c}$ \\
FI & $680.08 \pm 8.68 \mathrm{a}$ & $636.52 \pm 13.66 \mathrm{a}$ & $570.23 \pm 16.05 \mathrm{~b}$ & $516.75 \pm 21.50 \mathrm{c}$ \\
FCR & $3.84 \pm 0.09 \mathrm{a}$ & $4.26 \pm 0.16 \mathrm{a}$ & $4.31 \pm 0.27 \mathrm{a}$ & $5.20 \pm 0.50 \mathrm{a}$ \\
Mortality & 13.33 & 10.00 & 13.33 & 25.01 \\
\hline
\end{tabular}

FiBW: Final body weight (g), BWG: Body weight gain (g), FI: Feed intake (g), FCR: Feed conversion ratio

\section{Conclusion}

As a conclusion, that supplementation of diets with oak hydrolysed tannin has negative effect on FI, FCR, growth performance and mortality of quails. Further investigations are needed to determine the oak hydrolysed tannin on FI, FCR, growth performance and mortality of quails especially its toxic effects. Therefore farmers have to take care with supplementation of feed stuffs rich in hydrolysable tannin due to negative effects on both performance and mortality of quails.

\section{References}

Aggrey SE, Ankra-Badu GA, Marks HL. 2003. Effect of longterm divergent selection on growth characteristics in Japanese quail. Poultry Sci., 82(4): 538-542.

Cerit H. 1997. Japon bildırcınlarının (Coturnix coturnix japonica) çeşitli verim özelliklerine ait genetik ve fenotipik parametreler. Doktora Tezi. İstanbul Üniversitesi Sağlik Bilimleri Enstitüsü. İstanbul.

Cowan MM. 1999. Plant products as antimicrobial agents. Clin. Microbiol. Rev.,12(4): 564-82.

Ibrahim S, Fisher C, El-Alaily H, Soliman H, Anwar A. 1988. Improvement of nutritional quality of Egyptian and Sudanese sorghum grains by addition of phosphates. Brit. Poultry Sci., 29: 721-728.

Jimenez-Ramsey LM, Rogler JC, Housley TL, Butler LG, Elkin RG. 1994. Absorption and distribution of 14C-labeled condensed tannins and related sorghum phenolics in chickens. J. Agr. Food Chem., 4:963-967.

Khanbabaee K, Van Ree T. 2001. Tannins classification and definition. Nat. Prod. Rep.,18: 641-649.

Mahmood S, Khan MA, Sarwar M, Nisa M. 2008. Use of chemical treatments to reduce anti-nutritional effects of tannins in salseed meal: Effect on performance and digestive enzymes of broilers. Livest. Sci., 116: 162-170.
Mangan JL. 1988. Nutritional effects of tannins in animal feeds. Nutr. Res. Rev., 1: 209-231.

McSweeney CS, Palmer B, McNeill DM, Krause DO. 2001. Microbial interactions with tanning polyphenolics: nutritional consequences for ruminants. Anim. Feed Sci., Tech. 91: 83-93.

Nazlıgül A, Türkyılmaz MK, Bardakçıoğlu HE. 2005. Effects of hatching egg weight on hatching chick weight, post hatching growth performance and liveability in Japanese quails (Coturnix coturnix japonica). İstanbul Üniv. Vet. Fak. Derg., 31 (2): 33-40.

Nyachoti CM, Atkinson JL, Leeson S. 1997. Sorghum tannins: a review. World Poultry Sci. J., 53: 5-21.

Özcan M, Ekiz B, Güneş H. 2001. Japon bıldırcınlarında (Coturnix coturnix japonica) gruplandırılmış yumurta ağırlığı ve çıkım ağırlığının büyüme performansı üzerine etkileri. İstanbul Üniv. Vet. Fak. Derg., 27(2): 577-584.

Priolo A, Waghorn GC, Lanza M, Biondi L, Pennisi P. 2000. Polyethylene glycol as a means for reducing the impact of condensed tannins in carob pulp: effects on lamb growth performance and meat quality. J. Anim. Sci., 78: 810-816.

Sarica M. 1998. The effects of light colour and lighthing regimes on the quail growth and carcass traits. Turk. J. Vet. Anim. Sci., 22: 103-110.

Schofield P, Mbugua DM, Pell AN. 2001. Analysis of condensed tannins: a review. Anim. Feed Sci. Tech., 9: 2140.

Trevino J, Ortiz L, Centeno C. 1992. Effect of tannins from faba beans (Vicia faba L.) on the digestion of starch by growing chicks. Anim. Feed Sci. Tech., 37(3-4): 345-349.

Vilarino M, Metayer JP, Crepon K, Duc G. 2009. Effects of varying vicine, convicine and tannin contents of faba bean seeds (Vicia faba L.) on nutritional values for broiler chicken. Anim. Feed Sci. Tech., 150: 114-121. 